\title{
Four Patients With Different Characteristics in Smoking and Cessation-Case Series
}

\section{Sigarayı İçme ve Bırakma Konusunda Farklı Özellikte Dört Hasta- Olgu Serisi}

Mustafa Ünal ${ }^{1}$, Onur Öztürk ${ }^{* 2}$, Mustafa Yasin Selçuk ${ }^{1}$, Bektaş Murat Yalçın ${ }^{1}$

\begin{abstract}
Smoking is one of the worst habits adversely affect health. Various reasons can play a part in starting smoking. Addictions are difficult to combat for various reasons. In our manuscript, four patients with different characteristics in smoking and cessation were presented.
\end{abstract}

Key words: Smoking, hookah, punishment, internship experience, excuse

\section{ÖZET}

Sigara, sağlığa olumsuz etkide bulunan en kötü alışkanlıklardandır. Sigaraya başlama nedenleri çok çeşitli olabilmektedir. Bağımlılıklarla çeşitli nedenlerle mücadele edilmesi zordur. Makalemizde, sigarayı içme ve bırakma konusunda farklı özellikte dört hasta sunulmuştur.

Anahtar kelimeler: Sigara, nargile, ceza, staj deneyimi, bahane

Received Date / Geliş tarihi: 17.03.2018, Accepted Date / Kabul tarihi: 26.04.2018

${ }^{1}$ Ondokuz Mayıs University Faculty of Medicine, Department of Family Practice, SAMSUN

${ }^{2}$ Asarcık Family Healthcare Center, Clinic of Family Practice, SAMSUN

*Address for Correspondence / Yazışma Adresi: Onur Öztürk, Asarcık Family Healthcare Center, Clinic of Family Practice, SAMSUN

E-mail: dr.onurozturk@yahoo.com

Ünal M, Öztürk O, Selçuk MY, Yalçın BM. Sigarayı İçme ve Bırakma Konusunda Farklı Özellikte Dört Hasta- Olgu Serisi. TJFMPC, 2018;12(4) 322-328

DOI: $10.21763 /$ tjfmpc.465776 


\section{INTRODUCTION}

Smoking is one of the worst habits adversely affect health. Medical students have the opportunity to observe closely these health consequences. Despite all this, smoking is increasing alarmingly among medical students. Various reasons can play a part in starting smoking. The usual reasons are pleasureseeking behaviour, a desire to experience something new, or curiosity. Usually, people do not start smoking to be addicted or to harm themselves. Addictions are difficult to combat for various reasons. Chemical and psychological mechanisms play roles and they all need to be addressed in intervention. While pharmacotherapy and psychotherapy in the form of motivational techniques are used, defence mechanisms of the mind are often overlooked. The mind uses some logical arguments to keep the addiction intact.

Hookah has a more innocent image in the society than smoking. In reality, hookahs are as harmful and addictive as cigarette smoking. Hookah cafes are established around the city and the customers usually have hookah and socialize. Presentation of the hookah with different pleasant smells, flavouring and colouring agents in these cafes attracts young people.

In this case series, we will talk about four interesting cases of patients that applied to our smoking cessation clinics, who quitted smoking by vocational training experience, who produced excuses not to quit smoking, who wanted to suffer from cigarette smoking and who became a regular smoker after testing nicotine forms.

\section{CASE- 1}

\section{The Effect of Chest Diseases Internship and Asthma Attack on Quit Smoking}

\section{Background}

The years of university studenthood are one of the most turbulent stages of development, and the last phase of adolescence, which is considered to be a transitional period, both social and biologically. ${ }^{1}$ This period is hard and risky for everyone but it may be harder for medical students. Medical students gain access to medical schools after years of hard and disciplined work along with the close family support. Once they succeed they feel that the task is completed and they can relax. Most of them move away from their family losing one of the fundamental supports. The peer influence gets stronger. ${ }^{2}$ This is a good breeding ground for addictions and many bad habits.

Although medical students are thought mainly health and diseases, the first year of the curriculum does not allow students to develop the desired health conscience. Firstly if the school is teaching in a foreign language the first year is spent for language training when students don't pass the compatibility exam. When the students make it to the first term, the training is mainly about normal topography such as anatomy rather than the actual diseases with their causes. Furthermore, these lessons are hard and students are expected to acquire large volumes of knowledge in a relatively short time. In fact, burnout rates among medical students are found to be quite high. ${ }^{3}$ In this atmosphere, they resort helper techniques and substances they hear or believe. Some of these substances are energy drinks, caffeine or tobacco. Our case illustrates this relation very clearly.

\section{Case Report}

Our case, an intern doctor, is seeking advice on not restart smoking during a tobacco cessation seminar we held regularly. He also proposed a method of smoking cessation he believed would be very effective. He thinks visiting and working some time in chest disease department would be very effective. Had he been smoking by the time his work in this department he was sure he would definitely give up. When he is asked how he stopped the answer was a severe asthma attack requiring hospital treatment.

His detailed history revealed somewhat alarming information. In his words 'we were sweet, naïve and good Anatolian boys who achieved a good success by entering the medical school'. He shared a house with other students and his friends' circle included around 15 students. At the beginning only four or five of them were smokers. In time, a result of late nights, long studying hours and sometimes alcohol they were all smokers in the first term.

He knew he was asthmatic and he was warned against smoking since his childhood. But when he tried smoking for the first time it didn't seem to affect him badly. After seven years of smoking, he knew his health was affected badly. One day he smoked when he had a mild respiratory infection and suddenly suffered an asthma attack. Following this frightening choking feeling he stopped smoking. During his work in the chest department, seeing all those smoking-related problems he was happy for giving up. Every smoker should spend some time in this environment he thinks.

\section{Discussion}

Tobacco cessation is a very difficult challenge. Relapse rates are disappointingly high and nicotine addiction tricks people in many different forms and tactics. Scare tactics often do not work. ${ }^{4}$ Tobacco 
counseling and close follow up seem to work best. But close experience to catastrophic consequences also seem to work on some occasions. People who witness someone close suffer badly or experience a severe health problem themselves may give up smoking suddenly.

According to Mayda et al. the probability of starting smoking is significantly higher in those who live with friends compared to those who stay with the family. ${ }^{5}$ Fidanc1 et al. reported that the most common cause of cigarette smoking in society is affectation. ${ }^{6}$ Therefore, in our medical schools there should be some steps to prevent young people fall into the trap of addictions. These may be; Mentor clinicians, stricter tobacco control measures among students and early education models of health and diseases along with their relations to addictions. Perhaps early visits or limited works with $\mathrm{COAH}$ patients or cirrhosis patients with alcohol-related problems may be effective. Clinical studies are required in this field.

CASE- 2

Mind Games: Protecting Addictions Including Smoking

\section{Background}

Smokers initially start smoking for pleasure. But after the addiction is established they carry on smoking because they cannot bear the unpleasant feelings of abstinence. ${ }^{7}$ But the health risks related smoking is so great the fight against smoking is gaining momentum in the world. As different health professionals are joining in this fight all advice their patients to quit. ${ }^{8}$ The accumulation of knowledge about smoking-related health problems and public campaigns against smoking puts pressure on smokers. ${ }^{9}$ Smoking is an irrational activity inflicting heavy damage on smokers and bystanders. But the addiction power of smoking is so great, quitting attempts often fail or high relapse rates occur.

Human mind builds psychological defence mechanisms to face problems. ${ }^{10}$ These defence mechanisms make our shortcomings in the world bearable and help us to maintain our integrity. In the case of smoking everyone knows that smoking is a dangerous and irrational activity that cannot be defended easily as a pleasure or freedom of choice. But giving up is very difficult. Nicotine has a strong addiction power and unpleasant feelings are so bothersome in abstinence, relapse occurs quite often. ${ }^{11}$ Therefore smokers make efforts to protect this addiction in conscious or subconscious levels. ${ }^{12}$ Defence mechanisms may come in various ingenious forms that difficult to combat. For example, as we see often in our clinic, the mind creates two or more possible hazardous scenarios; one is smoking and the other is usually more hazardous i.e. putting on excessive weight, failing at work due to lost concentration and getting too angry that some criminal activity may occur. ${ }^{13}$ So, In the mind of a smoker clearly, smoking is the lesser evil. In the case below the duo was smoking or breaking the unity of the family.

\section{Case Report}

Fifty-yearold house woman applied to our clinic for smoking cessation. She expressed strong desire to quit. Her husband was smoking sometimes just to accompany her but did not smoke otherwise. Her son was a smoker. She usually smoked in the kitchen as smoking outside was not appropriate for women where she lived. Her Fagerstrom score was 8 and she smoked 20 a day. She described smoking 3-4 cigarettes in a row in the morning with a Turkish coffee after her husband gone to work was one of the biggest pleasures in life. 'Cigarette has been my best company for 25 years and I don't know how to apart from it' she said. She lived abroad and came back for a few months. She was going to have dental implant treatment and the surgeon advised her to quit strongly if the dental implant were to be successful. That was her main reason for applying to our clinic.

A smoking cessation program is made in combination with pharmacotherapy and psychotherapy. Motivational measures are taken i.e. changing the brand, smoking times and places. She objected to change brand as she brought many packs to cover all holiday period. Bupropion 150 $\mathrm{mg}$ daily for 3 days initially followed by $300 \mathrm{mg}$ in two doses is planned. A quit day is agreed upon and she was called in again 3 days after quitting. She was told to get rid of all remaining cigarettes.

Four days after agreeing with a quit plan she came back complaining that the drug was making her sleepy. This was creating a social problem because her husband also arrived and she was expected to accompany him visiting families in the village. She stated 'it's impossible to stay awake. Can I stop taking drugs until he is gone back?' Her husband was planning to go back abroad in one or two weeks. According to the patient centred care principles, this was agreed. Three weeks later she came back to the clinic because the smoking cessation hotline, 171, insisted. She did not want to come because she couldn't stop smoking. She said that she was very surprised to see that restarting bupropion did not cause any sleepy feeling at all. When she offered a new quitting day and a fresh program she raised concern about going back abroad shortly and she did not have sufficient time left. She is advised to stick to the program and 
attend cessation clinics when she can. She did not report back until this article is written which was after more than 3 months.

\section{Discussion}

Smokers make efforts to protect their habits. It is often difficult to admit that a person is unable or unwilling to quit in the face of health hazards and family/friend pressures. ${ }^{14}$ Instead they use defence mechanisms such as rationalization. ${ }^{15}$

In our case, the dentists and the family pressures were too great for her to resist. Conveniently the drug caused excessive sleepiness to a point where she could not fulfill her social duties. But later, after all settled, the drug was not making her sleepy any more. Defensive mechanisms cause obstacles to therapy; in fact, people may not even be aware that they produce excuses. ${ }^{16}$ Our patient realized later that the same medication did not cause sleepiness. This could be attributed to the development of tolerance to the drug. However, this is unlikely because of the smoking situation and no serious quitting attempt is made. Where she lived to have smoking cessation therapy was very difficult. So it will have to wait until she comes back again. In this way, she avoided the stress of quitting cigarettes now and bought time until the next visit sometimes in the future.

Perhaps followings can be considered as telltale signs that she was going to defend her habit: keeping remaining cigarettes, being forced to apply to cessation clinic by implant doctor and family, using almost a romantic language about smoking. However, all these need testing with controlled studies. ${ }^{17}$

In the clinic, we suspected that she was trying to protect her addiction subconsciously when she complained of excessive sleepiness. But as family physicians, we were mandated by principals of family medicine. One such principle is the patient centred approach in which all decisions are shared between patient and the physician and all concerns of the patients are addressed. Perhaps in dealing with addicts more paternal approach is required as patients are no longer in control of their addiction. Generally attempts to utilize behavioural cognitive approaches are difficult as patient's reasoning may seem too realistic. Patients may have difficulty to comprehend complex psychological defence mechanisms. Knowing the patient better and increasing the number of sessions may help the therapist to defeat the defensive mechanisms.

\section{Conclusion}

Patients use various defence mechanisms to protect their habits. The more paternal approach may be required dealings with addiction. Counsellors should be aware of such mechanisms and try to overcome them. All patients should be brought to a level of acceptance that nothing is more harmful than smoking and smoking should be ceased at all costs.

\section{CASE-3}

\section{An Interesting Self-Harm Method: Smoking Background}

Self-injurious behaviour is giving damage to one's own body without the intent to kill. ${ }^{18}$ The reasons for this behaviour pattern are not fully understood. This behaviour manifests usually in the forms of self-mutilation with a razor or a sharp object in different parts of the body. Self-harming behaviour in young children may have the purpose of punishing the parents. These behaviours might manifest as not controlling urine or bowel movements, slapping themselves or banging their heads. Similar behavioural patterns in various forms may persist in the later ages.

Self-injurious behavior, a severe behavioural pathology, is most frequently seen in Borderline Personality Disorder. However, they are also often seen in substance abuse, mental retardation, impulse control disorders, major depression, posttraumatic stress disorder, dissociative disorders, and psychotic disorders. ${ }^{19}$

The harms of cigarette are now known to everyone. Governments, health authorities, various organizations and persons are fighting a relentless battle against cigarettes to prevent these harms. Within the scope of this battle, over expressions of a battle terminology or exaggerated scare terminology can be used. So the cigarette can be perceived as a handgun killer ready to kill. This perception might have the unintended effect on some people who have susceptible personality.

\section{Case Report}

An 18-year-old male patient applied to our clinic for smoking cessation treatment. He had a higher level of culture and more mature behaviour than his age. He was living alone and studying at the university as well as preparing for university exams at the same time. His tobacco dependence scores were moderate. Detailed history revealed that he was an enemy of the cigarettes. He described his feelings as 'Smoking was worse than suicide.' $\mathrm{He}$ had a nervous personality. If his friends smoked he used mobbing to stop them. If his father smoked at home he sent him out to the balcony. When his reasons for starting smoking are asked he gave the 
following information. His father was doing apiary work and he was taking his bees to the east of the country in the summer months. While his father was in the east the terrorist activities in that area had increased greatly and he was very worried about his father. He had a bad argument with his girlfriend at the same time. Things weren't going well in his university preparation classes. On that day he had a hard debate on a question with his teacher. He felt very bad. So he wanted to harm himself, bought a packet of cigarettes from the grocery store and finished them on the same day. The next day he did the same and couldn't stop smoking since then despite his efforts. Anger control studies were performed with the patient with the Focus on motivational counseling. A smoking cessation program is made including bupropion. The patient came to his sessions regularly and stopped smoking without difficulty.

\section{Discussion}

The self-injurious behaviour identified in our patient was assessed as a new diagnostic category in DSM-5, under the 'other situations where clinical attention should be focused' as 'history of personal self-harming behaviour'. Intentional self-injurious behaviour is defined as 'intentional bodily-mentally harm five or more times in a year causing pain bruising or bleeding. The intention is to cause mildmoderate bodily harm. For this diagnosis, the behaviour should not be identified as normal in the society and should not be limited to activities like lifting the scab or eating nails. the behaviour or outcomes should cause clinically significant impairment or impairment in the areas of interpersonal, academic, or other important functioning. ${ }^{20}$ It may be argued that our patient is harming the whole body by smoking, affecting social life and academic success negatively. However, smoking doesn't fit fully in this category even though the intention of the patients exactly aims that.

Self-injurious behaviour can occur in different forms. When people cannot cope with the difficulties of life, they can express themselves in extreme ways. Self-harmful behaviour may not be only manifest with self-mutilation. Patients may exhibit harmful behavior in a variety of ways. Smoking as a self-harm is a very rare condition in the clinic. Durmuş et al. reported a case in which the patient had burned some parts of own body with cigarettes. ${ }^{18}$ In our case smoking is preferred to harm the whole body. Exaggerated jargon for strengthening the effectiveness of the fight against tobacco may trigger unusual behaviours to be effective in fighting cigarettes, those who tend to use discourses other than scientific can lead to different behavioural patterns. For this reason, students can come home from primary school crying and begging their parents to quit smoking. Some young people can choose to smoke for the self-punishment method as a result of exaggerated perception. When the punishment they desire does not realise quickly they may be left with the addictions for life.

Riala et al. It has been shown that cigarette smoking among rats may lead to self-injurious behaviour. $^{21}$ Çimen et al. Reported that cigarette use in parents did not affect the self-harm behaviour. $^{22}$ In our case, the fact that our father was a smoker may have triggered self-harm behaviour.

Treatment of self-injurious behaviour requires mixed approaches as it's aetiology multifactorial. Psychotherapeutic or pharmacological approaches can be selected in the treatment. ${ }^{23}$ Both methods have been used successfully in our patient who remains free from smoking.

\section{CASE-4}

\section{Jumping From Hookah to Regular Smoking}

\section{Background}

Smoking is one of the most common addictions and causes many health problems. Nicotine is the substance responsible for this addiction. ${ }^{24}$ Nicotine is as addictive as heroin. ${ }^{25}$ People start using nicotine for pleasure initially. After the addiction sets in, nicotine is sought to alleviate abstinence symptoms. Abstinence symptoms and cravings for nicotine get so severe; they seek nicotine regardless of the delivering device. Any device that delivers nicotine through inhalation alleviates nicotine cravings. For this reason a person may start using hookah and progress on to cigarettes or more commonly use them both. ${ }^{26}$

All devices that deliver nicotine through inhalation can start nicotine addiction. Water pipes or hookahs are considered less dangerous than tobaccos. ${ }^{27}$ In reality hookah smoking has serious health consequences. ${ }^{28,29}$ Also hookah houses are established around the cities in the image of decent places to socialize. They are mainly designed to attract young people. Young man and girls sit in a pleasant environment and smoke hookahs. Pleasant smells and flavourings in these hookahs together with the atmosphere lure young people to try hookahs. ${ }^{30}$ Soon they become addicted to nicotine and start seeking other convenient nicotine suppliers, i.e. cigarettes. Our case is an example of this

transition. 


\section{Case Report}

A university student male smoker aged 22 applied to our clinic for smoking cessation therapy. His Fagerstrom scoring was 8 (heavy smoker). He was studying in Cyprus and got concerned about his health after he could not run in the football match as well as he used to. He is aware of the dangers if he continues smoking. He tried unsuccessfully to quit a couple of times and decided to seek help. Psychological and pharmacological therapy is started.

He was asked how this cigarette addiction started. When he was a high school student he studied in a town a 100 kilometres away from home. In the last year of high school he was preparing heavily for the university exam. He was attending to university preparing a course in holidays in his hometown. After the course group of a few friends used to visit a hookah house and revise the lessons while smoking hookah. When the holiday was over he went back to his school and to his surprise, he was craving for hookah. Craving was so strong he sought advice from his hookah mates. They simply told him to smoke cigarettes instead. He smokes since then and now he regularly smokes 20 cigarettes a day. Asked if he still smokes hookahs, he confirmed and added he occasionally smokes cigars, pipes and even electronic cigarettes. He is specifically requested to stay away hookah houses and any social settings where smoking takes part because he was hooked on cigarettes through the hookah. He stated that might be very difficult as anti-smoking policies in Cyprus was not rigorous and smoking hookahs - even cigarettes are an integral part of social life.

\section{Discussion}

Tobacco addiction comes in many forms. Some of them are cigarettes, pipes, cigars hookahs and recently electronic cigarettes. Although they may look different they all cause addiction through nicotine. ${ }^{31}$ When it is inhaled it causes dopamine peaks and these peaks are instrumental for addiction.

Hookahs are served generally in hookah houses and cafes where young people attend. ${ }^{32}$ These houses supposedly allow people smoke hookah in open spaces. But many cover the garden or allocated space with plastic sheeting like a greenhouse therefore creating a closed space. Even if they allow hookah in an open space, various pleasant odours and smells coming from different additives make hookah attractive to young people. Hookah has a more innocent image in the society. Because the smoke goes through the water people think it is purified and less dangerous than smoking. These cafes have a pleasant atmosphere where young people socialize. No one uses the hookah with the intention of becoming a nicotine addict. People somehow think that addiction is for some other people. ${ }^{33}$ Because they are using hookah or other devices that deliver nicotine through inhalation for pleasure intentionally they think it's under control, therefore, they can stop whenever they want to. But in reality after the addiction sets in people quickly realize that they are no longer smoking for pleasure but to avoid unpleasant feelings when they don't take the nicotine. Our case illustrates that not all smokers start off with cigarettes.

\section{Conclusion}

For nicotine addiction dopamine surge is required in the brain. Inhaled nicotine provides dopamine surge with every puff hence creates powerful addiction. Hookahs are hooking young people into nicotine addiction. Public campaigns against hookah use and tighter control of hookah houses are required to fight tobacco.

\section{REFERENCES}

1. Özkan S, Yılmaz E. Üniversite öğrencilerinin üniversite yaşamına uyum durumları (Bandırma örneği). Fırat Sağlık Hizmetleri Dergisi, 2010;5(13):153-71.

2. Dyrbye LN, Thomas MR, Shanafelt TD. Medical student distress: causes, consequences, and proposed solutions. Mayo Clin Proc. 2005 Dec;80(12):1613-22.

3. Güdük M, Erol Ş, Yağcibulut Ö, Uğur Z, Özvarış ŞB, Aslan D. Ankara'da bir tıp fakültesi'nde okuyan son sinıf öğrencilerde tükenmişlik sendromu. Sted, 2005;14(8):16973.

4. World Health Organization. 2012 Global progress report on implementation of the WHO framework convention on tobacco Control. 2012;

44-50. http://apps.who.int/iris/bitstream/10665/79170/ 1/9789241504652_eng.pdf (Avaible: 04.04.2017 )

5. Mayda AS, Tufan N, Baştaş S. Düzce tıp fakültesi öğrencilerinin sigara konusundaki tutumları ve içme sıklıkları. Kor Hek 2007; 6 (5): 364-370.

6. Fidanci I, Ozturk O, Yalcin BM. Evaluation of the relation between reasons for initiating smoking and dependence level. J. Exp. Clin. Med., 2017; 34(1): 47-50.

7. Davis JM, Mills DM, Stankevitz KA, Manley AR, Majeskie MR, Smith SS. Pilot randomized trial on mindfulness training for smokers in young adult binge drinkers. BMC Complement Altern Med. 2013 Sep 3;13:215.

8. Redding CA, Rossi SJ, Rossi RS, Velicer WF, Prochaska JO. Health behaviour models. The 
International Electronic Journal of Health Education 2000; 3: 180-193.

9. Gifford EV, Kohlenberg BS, Hayes SC, Antonuccio DO, Piasecki MM, Hall MLR. Acceptance-based treatment for smoking cessation. Behavior Therapy 2004; 35(4), 689705 .

10. Benford RB, Gough B. Defining and defending 'unhealthy' practices: a discourse analysis of chocolate 'addicts' accounts. J Health Psychol. 2006 May;11(3):427-40

11. Hall SM, Munoz RF, Reus VI, Sees KL. Nicotine, negative affect, and depression. Journal of Consulting and Clinical Psychology 1993; 61:761-767.

12. Ockene JK, Mermelstein RJ, Bonollo DS, Emmons KM, Perkins KA, Voorhees CC, et al. Relapse and maintenance issues for smoking cessation. Health Psychol. 2000 Jan;19(1S):1731.

13. Velicer WF, Prochaska JO, Rossi JS, Snow MG. Assessing outcome in smoking cessation studies. Psychol Bull. 1992 Jan;111(1):23-41.

14. Curry SJ, Grothaus L, McBride C. Reasons for quitting: Intrinsic and extrinsic motivation for smoking cessation in a population-based sample of smokers . Addict Behav. 1997 NovDec;22(6):727-39.

15. Heikkinen H, Patja K, Jallinoja P. Smokers' accounts on the health risks of smoking: Why is smoking not dangerous for me? Soc Sci Med. 2010 Sep;71(5):877-83.

16. Pickard H. Denial in Addiction. Mind \& Language 2016; 31(3): 277-299.

17. Poland BD, Cohen JE, Ashley MJ, Adlaf E, Ferrence R, Pederson LL. Heterogeneity among smokers and non-smokers in attitudes and behaviour regarding smoking and smoking restrictions. Tob Control. 2000 Dec;9(4):36471.

18. Durmuş M, Tuncer SK, Öznur T, Yapıcı A, Bayram Y, Karapınar U. Self Mutilasyona Bağlı Yanık: Olgu Sunumu. Turk Plast Surg 2014;22(3).

19. Dulit RA, Fyer MR, Leon AC, Brodsky BS, Frances AJ. Clinical correlates of selfmutilation in borderline personality disorder. American Journal of Psychiatry 1994; 151, 1305-11.

20. American Psychiatric Association. Diagnosticand Statistical Manual of Mental Disorders, Fifth Edition. Washington, DC: American Psychiatric Association, 2013.

21. Riala K, Hakko H, Räsänen P; Study-70 Workgroup. Nicotine dependence is associated with suicide attempts and selfmutilation among adolescent females. Compr Psychiatry. 2009 Jul-Aug;50(4):293-8. doi: 10.1016/j.comppsych.2008.08.012. Epub 2008 Oct 16.
22. Çimen İD, Coşkun A, Nasıroğlu S, Etiler N. İzmit'te yaşayan ergenlerde kendine zarar verme davranışı ve aile özellikleri ile ilişkisi. Anadolu Psikiyatri Dergisi 2017;18(3):257-64.

23. Altındağ A, Bozgeyik Ö. Kendine Zarar Verme Davranışları. Turkiye Klinikleri J PsychiatrySpecial Topics 2009;2(1), 92-98.

24. Sanner T, Grimsrud TK. Nicotine: Carcinogenicity and Effects on Response to Cancer Treatment - A Review. Front Oncol. 2015 Aug 31;5:196.

25. WHO, 2014. Geneva. Neuroscience of psychoactive substance use and dependence. http://www.who.int/substance_abuse/publicatio ns/en/Neuroscience.pdf. Access: 17.11.2016

26. Richter L, Pugh BS, Smith PH, Ball SA. The co-occurrence of nicotine and other substance use and addiction among youth and adults in the United States: implications for research, practice, and policy. Am J Drug Alcohol Abuse. 2017 Mar;43(2):132-145.

27. Fauci GL, Weiser G, Steiner IP, Shavit I. Carbon monoxide poisoning in narghile (water pipe) tobacco smokers. CJEM. 2012 Jan;14(1):57-9.

28. Akl EA, Gaddam S, Gunukula SK, Honeine R, Jaoude PA, Irani J. The effects of waterpipe tobacco smoking on health outcomes: a systematic review. Int J Epidemiol. 2010 Jun;39(3):834-57.

29. Shihadeh A, Saleh R. Polycyclic aromatic hydrocarbons, carbon monoxide, "tar", and nicotine in the mainstream smoke aerosol of the narghile water pipe. Food Chem Toxicol. 2005 May;43(5):655-61.

30. Plummer BA, Velicer WF, Redding CA, Prochaska JO, Rossi JS, Pallonen UE, et al. Stage of change, decisional balance, and temptations for smoking measurement and validation in a large, school-based population of adolescent. Addict Behav. 2001 JulAug;26(4):551-71.

31. Centers for Disease Control and Prevention (CDC). Tobacco Product Use Among Middle and High School Students - United States, 2011 and 2012. Morbidity and Mortality Weekly Report (MMWR). 2013; 62(45);893-7.

32. Barnett TE, Curbow BA, Weitz JR, Johnson TM, Smith-Simone SY. Water Pipe Tobacco Smoking Among Middle and High School Students. Am J Public Health. 2009 Nov;99(11):2014-9.

33. Primack BA, Walsh M, Bryce C, Eissenberg T. Water-Pipe Tobacco Smoking Among Middle and High School Students in Arizona. Pediatrics. 2009 Feb;123(2):e282. 